\title{
ERRATUM
}

\section{The TGF- $\beta$-Smad3 pathway inhibits CD28-dependent cell growth and proliferation of CD4 T cells}

J-S Delisle, M Giroux, G Boucher, J-R Landry, M-P Hardy, S Lemieux, RG Jones, BT Wilhelm and C Perreault

Genes and Immunity (2013) 14, 132; doi:10.1038/gene.2013.4

Correction to: Genes and Immunity (2013) 14, 115-126; doi:10.1038/gene.2012.63; published online 17 January 2013

Since the online publication of the above article, the authors have noticed that in Table 2 , some of the decimal points were incorrectly removed. The correct table is given here:

The typesetters would like to apologise for this mistake.

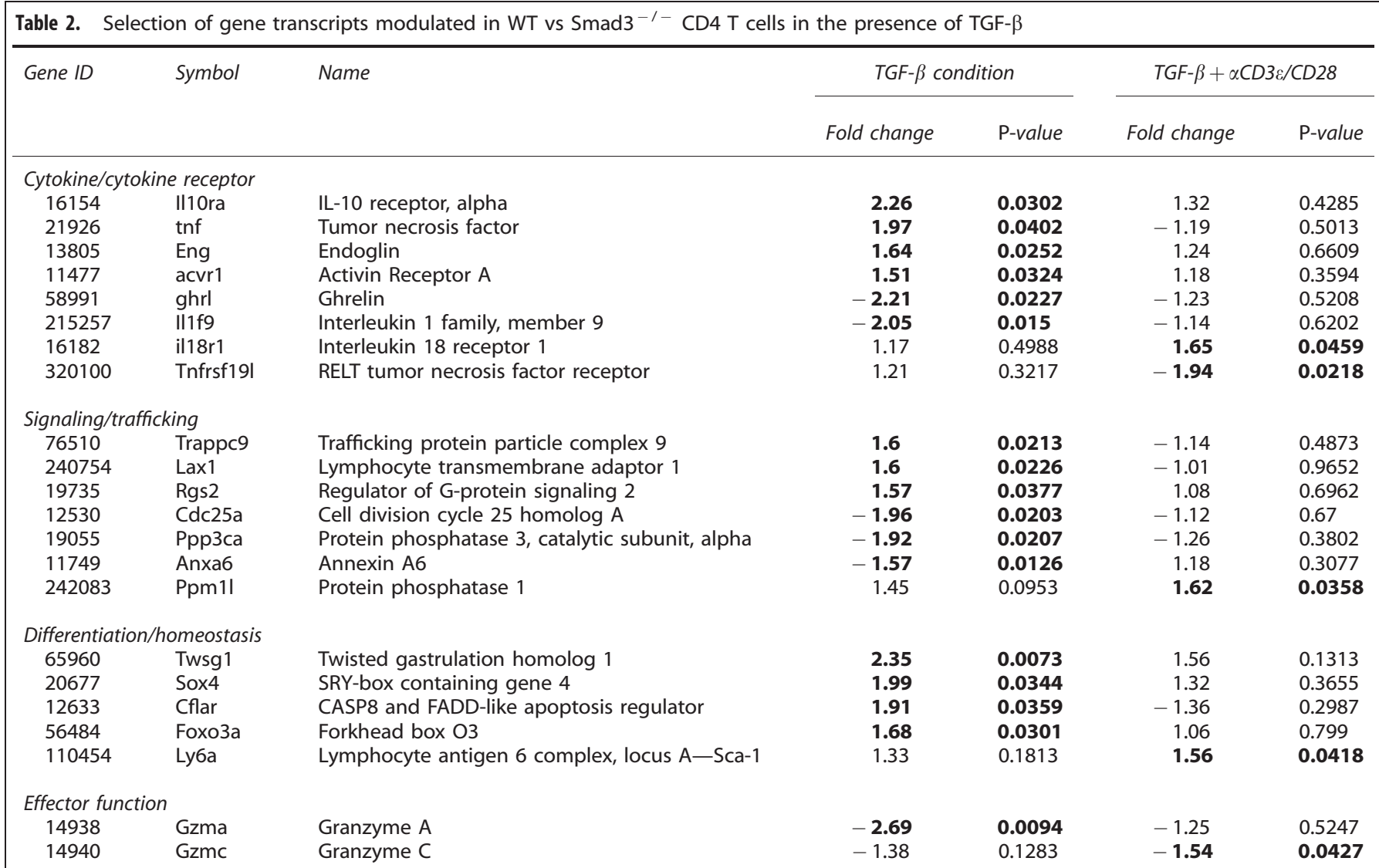

Abbreviations: TGF- $\beta$, transforming growth factor- $\beta$; WT, wild type. Transcripts differentially expressed by a factor of 1.5 -fold with a $P$-value $<0.05$ between WT and $\mathrm{Smad}^{-1-}$ cells are indicated in bold. 